\title{
İki Farklı Fakültede Öğrenim Gören Hemşirelik Öğrencilerinin Kariyer Geleceğine Îlişskin Görüşlerinin Değerlendirilmesi
}

\section{Evaluation of the Views of Nursing Students Studying in Two Different Faculties on Career Future}

\author{
Emine İlaslan ${ }^{1}$ (iD Simge Kalav ${ }^{1}$ (D) Abdullah Esirgenler ${ }^{1}$ (iD) Şiva Abdullah ${ }^{1}$ (D) Fidan Er $^{1}$ (D) \\ Esra Nur Tarhan ${ }^{2}$ (iD Ferda Güner ${ }^{2}$ iD \\ ${ }^{1}$ Akdeniz Üniversitesi Kumluca Sağlık Bilimleri Fakültesi, Hemşirelik Bölümü, Kumluca/Antalya, TÜRKIYYE \\ ${ }^{2}$ Akdeniz Üniversitesi Hemşirelik Fakültesi, Konyaaltı/Antalya, TÜRKIYYE
}

Gelis tarihi/ Date of receipt: 29/08/2020 Kabul tarihi/ Date of acceptance: 01/12/2020

(C) Ordu University Faculty of Health Sciences, Department of Nursing, Turkey, Published online: 31/12/2020

ÖZ

Amaç: Bu çalışma, farklı akademik ve klinik uygulama ortamlarında öğrenim gören hemşirelik öğrencilerinin kariyer geleceği, uyum ve iyimserlik düzeyleri arasında bir farklılık var mı sorusuna yanıt aramak amacıyla yapılmıştır.

Yöntem: Araştırmanın örneklemini ilçe kampüsünden 176, merkez kampüsten 225 olmak üzere toplam 401 hemşirelik öğrencisi oluşturmaktadır. Araştırma verileri “Öğrenci tanıtıı bilgileri formu” ile "Kariyer Geleceği Ölçeği” ile yüz yüze görüşme yöntemiyle toplanmıştır. Verilerin analizi için SPSS 23.0 programı kullanılmıştır. Verilerin analizinde tanımlayıcı istatistiklerin (ortalama, standart sapma, frekans) yanı sıra, iki grup arası değerlendirmelerde Mann Whitney U testi, ikiden fazla grup arası değerlendirmelerinde Kruskal Wallis testi; farklılığa neden olan grubun tespitinde ise post-hoc Games Howell testi kullanılmıştır.

Bulgular: İki farklı fakültede öğrenim gören öğrencilerin Kariyer Geleceği Ölçeği toplam ve alt boyut puan ortalamaları arasında anlamlı bir fark saptanmamıştır. Merkez kampüste öğrenim gören öğrencilerin Kariyer Geleceği Ölçeği toplam ve alt boyut puan ortalamaları ile "cinsiyet, mesleği kendi isteğiyle seçme, hemşirelikte bir modeli örnek alma, geleceğe yönelik mesleki pozisyonu planlama" değişkenleri arasında anlamlı fark bulunmuştur.

Sonuç: Öğrencilerin kariyer planlamaya ilişkin görüşlerinin akademik ve kinik ortamdan etkilendiği görülmektedir. Bu nedenle, okullar ve eğitimciler, hemşirelik lisans öğrencilerinin kendilerine özgü kariyer motivasyonuna daha fazla önem vermeli, daha iyimser olmalarını teşvik etmeli, daha profesyonel bir eğitim ortamı sunmalı ve kariyer uyumlarını teşvik etmek için rehberlik sağlamalıdır.

Anahtar Kelimeler: Kariyer geleceği, hemşirelik, öğrenci

\begin{abstract}
Objective: This study was conducted to find an answer to the question of whether there is a difference between the career future, adaptation and optimism levels of nursing students studying in different academic and clinical practice settings.

Methods: The sample of the study consists of 401 nursing students, 176 from the district campus and 225 from the central campus. Research data were collected by face-to-face interview method with "Student introductory information form" and " Career Futures Inventory ". SPSS 23.0 program was used for data analysis. In the analysis of the data, besides descriptive statistics (mean, standard deviation, frequency), Mann Whitney U test in evaluations between two groups, Kruskal Wallis test in evaluations of more than two groups; The post-hoc Games Howell test was used to identify the group that caused the difference.

Results: No significant difference was found between the Career Futures Inventory total and sub-dimension mean scores of the students from two different faculties. A significant difference was found between the total and sub-dimension averages of Career Futures Inventory students studying at the central campus and the variables of "gender, choosing the profession voluntarily, taking a model in nursing, planning a future professional position”.

Conclusion: It is seen that students' views on career planning are influenced by the academic and cynical environment. Therefore, schools and educators should place more emphasis on the unique career motivation of nursing undergraduate students, encourage them to be more optimistic, provide a more professional educational environment, and provide guidance to foster career adaptation.

Keywords: Career future, nursing, student
\end{abstract}

ORCID IDs of the authors: Eİ:0000-0003-2630-6617; SK: 0000-0003-2261-7813; AE: 0000-0002-1991-8845; ŞA: 0000-0002-7152-0498; FE: 0000-0001-5314-3388; ENT: 0000-0002-1094-4617; FG: 0000-0001-6628-995X

Sorumlu yazar/Corresponding author: Dr. Öğr. Üyesi Emine İlaslan

Akdeniz Üniversitesi Kumluca Sağlık Bilimleri Fakültesi, Hemşirelik Bölümü, Kumluca/Antalya, TÜRKIYE

e-posta/e-mail: emineilaslan@akdeniz.edu.tr

Atıf/Citation: İlaslan E, Kalav S, Esirgenler A, Abdullah Ş, Er F, Tarhan ES, Güner F. (2020). İki farklı fakültede öğrenim gören hemşirelik öğrencilerinin kariyer geleceğine ilişkin görüşlerinin değerlendirilmesi. Ordu Üniversitesi Hemşirelik Çalışmaları Dergisi, 3(3), 254-263.

DOI: $10.38108 /$ ouhcd.787739 


\section{Giriș}

Kariyer bireyin yaşamı boyunca üstlendiği iş rolüne ilişkin beklentilerini, arzularını gerçekleştirebilmesi için gerekli bilgi, beceri, yetenek ve motivasyonla donatilarak ilerlemesi olarak tanımlanmaktadır (Kalafat, 2012; Karadaş ve ark., 2017). Kariyer planlama ise sürekli bir öz değerlendirme ve hedef belirleme sürecidir. $\mathrm{Bu}$ süreçte bireylerin kariyer ile ilgili uyumluluk, iyimserlik ve bilgi düzeyinin değerlendirilmesi gerekmektedir (Rottinghaus ve ark., 2005). Kariyer uyumluluğu, "bireyin mevcut ve öngörülen görevler, geçişler, mesleki rollerindeki travmalar ile başa çıkma kaynaklarını gösteren bir psikososyal yapı" olarak tanımlanmıştır (Savickas ve Porfeli, 2012). Kariyere uyumluluğunun kariyer veya mesleki kimlik (Douglass ve Duffy, 2015; NegruSubtirica ve ark., 2015), okul deneyimleriyle ilgili memnuniyetler (Chan ve Mai, 2015; Zacher ve ark., 2015), iş stresi (Johnston ve ark., 2013), iş performans1 (Ohme ve Zacher, 2015), ekonomik gelirle (Guan ve ark., 2014) ilişkili olduğu gösterilmektedir. $\mathrm{Bu}$ nedenle uyum sonuçları, kişi ve çevre arasındaki uyumun iyiliği ve ayrıca gelişme, memnuniyet, bağlılık ve iş başarısı gibi göstergelerle belirtilmektedir. Kariyer iyimserliği, başarılı kariyer adaptasyonunda etkili olduğu bulunan önemli bir kaynak olarak bildirilmekte (Rottinghaus ve ark., 2005), bireylerin "mümkün olan en iyi sonucu beklemeleri veya kişinin gelecekteki kariyer gelişiminin en olumlu yönlerini vurgulama eğilimi" olarak tanımlanmaktadır (Rottinghaus ve ark., 2012; Rottinghaus ve ark., 2005). İş piyasasına ilişkin algılanan bilgi ise bireylerin iş piyasasını ve istihdam eğilimlerini algilama düzeyi olarak bildirilmektedir (Kalafat, 2012).

Kariyer planlamasının tüm sektörlerde olduğu gibi hemşirelik mesleğinde de hem öğrenci hem de mezun hemşireler açısından akademik ve klinik ortamlarda tartışılması önemlidir (Waddell ve ark., 2015). Eğitim ortamında lisans öğrencileri, öğretim elemanlarından ve akranlarından destek almakta, meslekler veya kuruluşlar hakkında bilgi edinmekte, mesleki yeterliliklerini ve ilgi alanların geliştirmektedir (Lazarides ve ark., 2016). Öğrenciler farklı klinik alanlarda uygulamalar yaparak farklı deneyimler yaşamakta, bazı stresörlerle karşılaşabilmektedir. Stres faktörleri arasında; yetersizlik hissi, hasta ve klinik personel ile zor ilişkiler, duygusallık, hastalık ve ölüme tanıklık etme gibi aşırı duygusal yüklenmeler yer almaktadır (Imanipour ve ark., 2015). İyi klinik ortamları ise öğrencinin katılımını ve öğrenmeyi teşvik ederek, öğrencilerin pozitif duygularla o ortamdan ayrılmalarını sağlamaktadır. Dolayısıyla klinik uygulama ve akademik ortamların geleceğe yönelik planları etkilemesi nedeniyle özyönetim, kararlılık, kariyer planlama ve benzeri becerilerinin hemşirelik öğrencilerine daha lisans eğitim yıllarında kazandırılması gerekmektedir (Kalafat, 2012; Mahendran ve ark., 2015). Öğrencilerinin lisans eğitimini tamamlamadan kariyer planı yapmaları ve meslekleri ile ilgili olumlu düşünce geliştirmeleri aynı zamanda mesleğin gelişimine de katk1 sağlamaktadır (Cevher, 2015; Lazarides ve ark., 2016).

Ülkemizde 2020 y1lı itibariyle 141 üniversitede 157 Hemşirelik Bölümünde aktif olarak hemşirelik lisans eğitimi verilmektedir (https://yokatlas.yok.gov.tr/lisans-

bolum.php?b=10248, Erişim Tarihi: 19.08.2020). $\mathrm{Bu}$ okulların bir kısmının yerleşkesi merkez kampüslerde yer almakta, öğrenciler donanımlı hastanelerde ve sağlı merkezlerinde klinik uygulama yapabilmektedir. Ancak azımsanmayacak sayıda okulun yerleşkesi ise kampüs dışında ve ilçelerde yer almakta, öğrencilerin klinik uygulama alanları da kısitlı olabilmektedir. Fakültelerin kampüs içinde yer almaması ve ana kampüsten uzak ilçelerde bulunmasının öğrencilerin kariyer geleceklerine ilişkin düşüncelerini etkilediği varsayılmaktadır. $\mathrm{Bu}$ doğrultuda araştırmamız aşağıdaki sorulara yanıt aramak amaciyla yapılmıştır.

\section{Araştırma soruları}

1. İki farklı akademik ve klinik uygulama ortamlarında öğrenim gören hemşirelik öğrencilerinin kariyer geleceği, kariyer uyumluluğu ve iyimserliği, iş piyasalarına ilişkin algılanan bilgi düzeyleri puan ortalamaları arasında fark var midır?

2. İki farklı akademik ve klinik uygulama ortamlarında öğrenim gören hemşirelik öğrencilerinin tanıtıcı özelliklerine göre kariyer geleceği ölçeği toplam ve alt boyut puan ortalamaları arasında fark var mıdır?

\section{Yöntem}

\section{Araştırmanın Tipi}

$\mathrm{Bu}$ araştırma aynı üniversiteye bağlı iki farklı fakültede öğrenim gören hemşirelik öğrencilerinin kariyer iyimserliği, kariyer uyumu ve iş piyasalarına ilişkin algılanan bilgi düzeylerinin ve ilişkili faktörlerin belirlenmesi, karşılaştırılması amacıyla tanımlayıcı tipte yapılmıştır. 


\section{Araştırmanın Örneklemi}

İlçe kampüsünde yer alan fakülte merkez kampüse $100 \mathrm{~km}$ uzakl1kta ve fakültede birinci, ikinci, üçüncü sınıflar olmak üzere yaklaşık 220 hemşirelik öğrencisi öğrenim görmektedir. Araştırmanın yapıldığ 1 diğer fakülte ise merkez kampüs içerinde yer almakta ve fakültede yaklaşık 1000 öğrenci öğrenim görmektedir. Araştırmanın yapıldığı tarihte ilçe kampüsünde henüz dördüncü sınıf öğrenci olmadığı için her iki fakültenin son sınıf öğrencileri araștırmaya dahil edilmemiștir. Araştırmanın örneklem seçimine gidilmeyerek evrenin tamamına ulaşılmaya çalışılmış, araştırmaya katılmayı kabul eden öğrenciler bu kapsama alınmıștır. Araştırma ilçe kampüsünden 176, merkez kampüsten 225 olmak üzere toplam 401 hemşirelik öğrencisi ile tamamlanmıştır. Çalışma sonrası yapılan güç analizinde (Post-Hoc), çalışma örnekleminin $\% 2$ etki büyüklügünde, $\% 95$ güven aralığında \%93 güç sağladığı bulunmuştur.

\section{Araştırma verilerinin toplanması}

Araştırma verilerinin toplanması için; veri toplama araçları ve araştırma hakkında kısa bilgiyi içeren online anket formu hazırlanmıștır. Hazırlanan anket formu araştırmacılar tarafindan her iki fakültenin öğrencilerine ulaştırılarak araştırma verileri toplanmıştır.

\section{Veri toplama araçları}

Öğrenci tanıtıcı bilgileri formu: Araştırmacılar tarafindan oluşturulan öğrenci tanıtıcı bilgileri iki bölümden oluşmaktadır. Birinci bölümde cinsiyet, yaş, sınıf, mezun olunan okul, yaşanan yer, yabancı dil seviyesinin değerlendirildiği sorular yer almaktadır. İkinci bölümde mesleğine yönelik değerlendirmeleri içeren hemşirelik bölümünü tercih etme sebebi ve üniversite seçme sınavındaki tercih sırası, kendi isteğiyle seçme durumu, mesleğe yönelik kariyer planları, örnek model alma durumu, fakültede kariyer gelişim programlarının düzenlenme durumu, bulunduğu fakültede öğretim elemanı sayısının yeterliliği ve klinik uygulama yapılan hastane türünün değerlendirildiği sorular yer almaktadır.

Kariyer Geleceği Ölçeği: Türkçe'ye Kalafat (2012) tarafindan uyarlanan Kariyer Geleceği Ölçeği (KARGEL) Rottinghaus ve arkadaşları (2005) tarafindan bireylerin kariyer planlama tutumlarını değerlendirmek amaciyla geliştirilmiştir. Ölçek 3 alt boyuttan ve toplam 25 maddeden oluşmaktadır. Alt boyutlar kariyer uyumluluğu (KU), kariyer iyimserliği $(\mathrm{KI})$ ve iş piyasalarına ilişkin algılanan bilgi (AB) olarak sıralanmaktadır. Ölçek likert tipinde 1-5 arası derecelendirme ile değerlendirilmektedir. Maddelere verilen yanitlar $1=$ kesinlikle katılmıyorum, 2=katılmıyorum, 3=emin değilim, 4=kat1liyorum, $\quad 5=$ kesinlikle kat1liyorum şeklindedir. KU, alt boyutu 11 maddeden, Kİ alt boyutu 11 maddeden ve $A B$ alt boyutu ise 3 maddeden oluşmaktadır. Ölçek 15 olumlu, 8 olumsuz madde içermekte, ölçeğin içerdiği ters maddelerde puanlar tersine çevrilmek kaydiyla bütün maddeler 1-5 arası puanlanmaktadır. KU ve Kİ alt boyutlarından alınabilecek en yüksek puan 55 , en düşük puan ise 11, $\mathrm{AB}$ alt boyutundan ise en yüksek puan 15, en düşük ise 3'dür.

\section{Verilerin Değerlendirilmesi}

Veriler SPSS 23,0 programinda değerlendirilmiş, istatiksel analizde KolmogrovSmirnov testi sonucunda değişkenlerin normal dağılıma uygunluk göstermediği saptanmıştır. Verilerin analizinde tanımlayıc1 istatistiklerin (ortalama, standart sapma, frekans) yanı sıra, iki grup aras1 değerlendirmelerinde Mann Whitney U testi, ikiden fazla grup arası değerlendirmelerinde Kruskall Wallis testi; farkl1lığa neden olan grubun tespitinde ise post-hoc Games Howell testi kullanılmıştır. Sonuçlar $\quad \alpha=0.05$ anlamlılık düzeyinde değerlendirilmiştir.

\section{Bulgular}

Bu çalışmada iki farklı fakültede öğrenim gören hemşirelik öğrencilerinin kariyer planlamaya ilişkin görüşlerinin karşılaştırılması incelenmiştir. Öğrencilerin tanıtıcı bilgileri ve kariyer geleceğine ilişkin görüşleri iki farklı başlık altında yer almaktadır. Tablo 1'de iki farklı fakültede öğrenim gören öğrencileri tanıtıcı özelliklerine ait bulgular yer almaktadır. Öğrencilerin tanıtıcı özellikleri incelendiğinde merkez kampüs öğrencilerinin \%74'ünün, ilçe kampüs öğrencilerinin \%59'unun kadın olduğu, yaş ortalamalarının merkez kampüs öğrencilerinin $20.36 \pm 1.39$, ilçe kampüs öğrencilerinin $19.89 \pm 1.27$ olduğu bulunmuştur. Hem merkez hem de ilçe kampüs öğrencilerinin çoğunluğunun (sırasılyla \%97, \%96) Fen, Anadolu ve Meslek Lisesi mezunu olduğu ve yabanc1 dil seviyelerinin orta olduğu belirlenmiştir. 
Tablo 1. Öğrencilerin tanıtıcı özelliklerinin dağılımı

\begin{tabular}{|c|c|c|c|c|c|}
\hline & & $\begin{array}{l}\text { Merkez Kampüs } \\
\text { n (225) }\end{array}$ & $\%$ & $\begin{array}{l}\text { İlçe Kampüs } \\
\text { n (176) }\end{array}$ & $\%$ \\
\hline \multirow[t]{2}{*}{ Cinsiyet } & Erkek & 58 & 26 & 2 & 41 \\
\hline & Kadın & 167 & 74 & 104 & 59 \\
\hline Yaş ortalaması & & $20.36 \pm 1,39$ & & $19.89 \pm 1.27$ & \\
\hline \multirow[t]{2}{*}{ Mezun olunan lise türü } & Sağlık Meslek Lisesi & 7 & 3 & 7 & 4 \\
\hline & $\begin{array}{l}\text { Diğer Liseler (Fen, } \\
\text { Anadolu, Meslek) }\end{array}$ & 217 & 97 & 169 & 96 \\
\hline \multirow[t]{3}{*}{ Sinif } & 1.Sinif & 40 & 18 & 61 & 35 \\
\hline & 2.Sinif & 72 & 32 & 61 & 35 \\
\hline & 3.Sinif & 113 & 50 & 54 & 30 \\
\hline \multirow[t]{3}{*}{ Yaşanan yer } & Yurt & 93 & 41 & 73 & 41 \\
\hline & Ev & 52 & 23 & 45 & 26 \\
\hline & Diğer & 80 & 36 & 58 & 33 \\
\hline \multirow[t]{3}{*}{ Yabancı dil seviyesi } & İyi & 9 & 9 & 9 & 5 \\
\hline & Orta & 118 & 52 & 72 & 41 \\
\hline & Zayif & 88 & 39 & 95 & 54 \\
\hline \multirow{2}{*}{$\begin{array}{l}\text { Hemşirelik bölümünün } \\
\text { kendi isteğiyle seçme }\end{array}$} & Evet & 116 & 52 & 115 & 65 \\
\hline & Hayır & 109 & 48 & 61 & 35 \\
\hline \multirow{6}{*}{$\begin{array}{l}\text { Hemşirelik bölümünü } \\
\text { tercih etme sebebi }\end{array}$} & Puanım & 102 & 45 & 79 & 45 \\
\hline & İş bulma olanağ 1 & 56 & 25 & 57 & 32 \\
\hline & Aile ve sosyal koşullar & 26 & 12 & 25 & 15 \\
\hline & Eğitimi & 23 & 10 & 6 & 3 \\
\hline & Ekonomik geliri & 9 & 4 & 9 & 5 \\
\hline & $\begin{array}{l}\text { Okulun bulunduğu } \\
\text { il/ilçeden dolayı }\end{array}$ & 9 & - & - & - \\
\hline \multirow{3}{*}{$\begin{array}{l}\text { Hemşirelik bölümünü } \\
\text { tecih etme sırası }\end{array}$} & İlk siralar & 171 & 76 & 114 & 65 \\
\hline & Orta siralar & 38 & 17 & 47 & 27 \\
\hline & Son siralar & 16 & 7 & 15 & 8 \\
\hline \multirow{4}{*}{$\begin{array}{lr}\text { Hemşirelikte } & \text { geleceğe } \\
\text { yönelik } & \text { kariyer } \\
\text { planları } & \end{array}$} & Akademik alanda ilerlemek & 83 & 37 & 72 & 41 \\
\hline & Klinik hemşire olmak & 85 & 38 & 59 & 33 \\
\hline & Özel dal hemşiresi olmak & 35 & 15 & 17 & 10 \\
\hline & Yönetici hemşire olmak & 22 & 10 & 28 & 16 \\
\hline \multirow{2}{*}{$\begin{array}{lr}\text { Kariyer } & \text { gelişim } \\
\text { sirasinda } \\
\text { model }\end{array}$} & Evet & 83 & 37 & 87 & 49 \\
\hline & Hayır & 142 & 63 & 89 & 51 \\
\hline \multirow{2}{*}{$\begin{array}{l}\text { Fakültede kariyer } \\
\text { gelişim proğramlarının } \\
\text { düzenlenme durumu }\end{array}$} & Evet & 147 & 65 & 22 & 13 \\
\hline & Hayır & 78 & 35 & 154 & 87 \\
\hline \multirow{2}{*}{$\begin{array}{l}\text { Bulunduğunuz } \\
\text { kampüste sosyal } \\
\text { aktiviteler yeterli olma } \\
\text { durumu }\end{array}$} & Evet & 120 & 53 & 4 & 2 \\
\hline & Hayır & 105 & 47 & 172 & 98 \\
\hline \multirow{2}{*}{$\begin{array}{l}\text { Bulunduğunuz } \\
\text { fakültede öğretim } \\
\text { üyesinin yeterli olma } \\
\text { durumu }\end{array}$} & Evet & 197 & 88 & 80 & 46 \\
\hline & Hayır & 28 & 12 & 96 & 54 \\
\hline Klinik uygulama alanı & $\begin{array}{l}\text { Tip Fakültesi Hastanesi } \\
\text { Devlet Hastanesi }\end{array}$ & 225 & 100 & 176 & 100 \\
\hline
\end{tabular}


Tablo 2. Öğrencilerin KARGEL ölçeği ve alt boyut puan ortalamalarının dağılımı

\begin{tabular}{lcccccc}
\hline KARGEL Alt Boyutları & \multicolumn{7}{c}{ Merkez kampüs } & \multicolumn{1}{c}{ İlçe kampüs } \\
& Min-max & $\overline{\mathbf{X}} \pm$ SS & Min-max & $\overline{\mathbf{X}} \pm$ SS & $\begin{array}{c}\text { Test değeri } \\
\text { (U) }\end{array}$ & $\mathbf{p}$ \\
\hline Kariyer uyumluluğu & $11-55$ & $37.63 \pm 5.50$ & $13-55$ & $38.14 \pm 6.13$ & 19308.50 & .66 \\
\hline Kariyer iyimserliği & $11-55$ & $35.21 \pm 5.37$ & $13-55$ & $35.894 \pm 5.17$ & 18608.50 & .345 \\
\hline $\begin{array}{l}\text { İş piyasasına ilişkin } \\
\text { alglanan bilgi }\end{array}$ & $3-15$ & $8.92 \pm 2.05$ & $3-15$ & $8.97 \pm 2.01$ & 19286.00 & .704 \\
\hline Toplam puan & $25-125$ & $81.74 \pm 10.72$ & $25-125$ & $82.98 \pm 10.53$ & 18678.00 & .420 \\
\hline
\end{tabular}

$\overline{\mathrm{X}}$ : Ortalama; SS:Standart sapma; U: Mann Whitney U; $(*) \mathrm{p}<0.05$ anlamlı

Hemşirelik bölümünü kendi isteğiyle seçme oranı merkez kampüs öğrencilerinde $\% 52$, ilçe kampüs öğrencilerinde \%65 olarak bulunmuştur. Hemşirelik bölümünü her iki fakülte öğrencilerinin \%45'inin puanına göre, merkez kampüs öğrencilerinin \%25'inin ve ilçe kampüs öğrencilerinin \%32'sinin iş bulma olanağına göre tercih ettiği saptanmıştır. Öğrencilerin hemşirelik bölümünü ilk sıralarda tercih etme oranı merkez kampüs öğrenci için \%76, ilçe kampüs öğrencileri için \%65 olarak bulunmuştur. Hemşirelikte geleceğe yönelik kariyer planları değerlendirildiğinde merkez kampüs öğrencilerinin \%37'sinin akademik alanda ilerlemek ve \%38'inin klinik hemşiresi olmak istediği, ilçe kampüs öğrencilerinin ise \%41'inin akademik alanda ilerlemek ve \%33'ünün klinik hemşiresi olmak istediği belirlenmiştir. Merkez ve ilçe kampüs öğrencilerinin çoğunluğu kariyer planlamasında bir modeli örnek almadığını (sırasıyla \%63, \%51) bildirmişlerdir. Merkez kampüs öğrencilerinin $\% 35^{\prime} \mathrm{i}$ kariyer gelişim programlarının düzenlendiğini, \%53'ü sosyal aktivitelerin ve \%88'i öğretim elemanı sayısının yeterli olduğunu ifade etmişlerdir. İlçe kampüsündeki öğrencilerin ise \%87'si kariyer gelişim programlarının düzenlenmediğini, \%98'i sosyal aktivitelerin yetersiz olduğunu ve $\% 54$ 'ü de yeterli öğretim elemanının olmadığını bildirmiştir. Tablo 2'de iki farklı fakültede öğrenim gören öğrencilerin kariyer geleceğine ilişkin bulgular yer almaktadır. KARGEL ölçeğinin toplam puan ve alt boyut ortalamalarının fakültelere göre dağılımına bakıldığında KU merkez kampüste $37.63 \pm 5.50$, ilçe kampüsünde $38.14 \pm 6.13$, Kİ merkez kampüste $35.21 \pm 5.37$, ilçe kampüsünde $35.894 \pm 5.17$, AB merkez kampüste $8.92 \pm 2.05$, ilçe kampüsünde $8.97 \pm 2.01$, KARGEL toplam puan1 merkez kampüste $\quad 81.74 \pm 10.72$, ilçe kampüsünde $82.98 \pm 10.53$ olarak bulunmuștur. İnceleme sonucunda; ilçe kampüsü ile merkez kampüs ögrencileri arasında alt boyutlar ve toplam puan ortalamaları açısından anlamlı bir fark bulunmamıştır $(\mathrm{p}>0.05)$.

Tablo 3'de öğrencilerin KARGEL toplam ve alt boyut puan ortalamalarının tanımlayıcı özelliklerle ilişkisine yönelik analiz sonuçları verilmiştir. Merkez kampüs öğrencilerinde KU alt boyutu açısından hemşirelik mesleğini kendi isteği ile seçenler ve seçmeyenler arasında anlamlı bir fark bulunmuş $(\mathrm{U}=5320, \mathrm{p}=0.030)$, hemşirelik mesleğini kendi seçenlerin KU puan ortalamasının, seçemeyenlerden daha yüksek olduğu saptanmıştır. Merkez kampüs öğrencilerinde KU alt boyutu açısından hemşirelikte bir modeli örnek alan ve almayanlar arasında anlamlı bir fark bulunmuş $(\mathrm{U}=4692, \quad \mathrm{p}=0.011)$, örnek bir modeli olan öğrencilerin KU puan ortalamasının daha yüksek olduğu belirlenmiştir. İlçe kampüs öğrencilerin KU puan ortalaması ile değişkenler arasında ise anlamlı bir fark bulunmamıştır ( $p>0.05)$. Merkez kampüs öğrencilerinde Kİ ile cinsiyet değişkeni arasında anlamlı bir fark bulunmuş ( $\mathrm{U}=4008, \mathrm{p}=0.050)$, erkeklerde KI'nin daha yüksek olduğu belirlenmiştir. İlçe kampüsündeki öğrencilerin KI ile değişkenler arasında anlamlı bir fark saptanmamıştır $\quad(p>0.05)$. Merkez kampüs 
öğrencilerinde $\mathrm{AB}$ ile cinsiyet değişkeni arasında anlamlı bir fark bulunmuş $(\mathrm{U}=3572, \mathrm{p}=0.004)$, erkek öğrencilerin $\mathrm{AB}$ puan ortalamasının daha yüksek olduğu belirlenmiştir. İlçe kampüsündeki öğrencilerin $\mathrm{AB}$ puan ortalaması ile değişkenler arasında ise anlamlı bir fark bulunmamıştır $(\mathrm{p}>0.05)$.

Tablo 3. Öğrencilerin tanıtıcı özelliklerine göre KARGEL toplam ve alt boyut puan ortalamalarının dağılımı

\begin{tabular}{|c|c|c|c|c|c|c|c|c|c|c|}
\hline \multirow[b]{2}{*}{ Boyutlar } & \multirow[b]{2}{*}{ Değişken } & \multicolumn{5}{|c|}{ Merkez Kampüs } & \multicolumn{4}{|c|}{ İlçe Kampüs } \\
\hline & & & $\mathbf{N}$ & $\overline{\mathbf{X}} \pm \mathbf{S S}$ & Test Değeri & $\mathbf{p}$ & $\mathbf{N}$ & $\overline{\mathbf{X}} \pm \mathbf{S S}$ & $\begin{array}{c}\text { Test } \\
\text { Değeri }\end{array}$ & $\mathbf{p}$ \\
\hline \multirow{4}{*}{$\begin{array}{l}\text { Kariyer } \\
\text { uyumluluğu }\end{array}$} & Hemşirelik & Evet & 116 & $38.41 \pm 4.658$ & \multirow[b]{2}{*}{$\mathrm{U}=5320.00$} & \multirow[b]{2}{*}{$.030 *$} & 115 & $38.53 \pm 5.862$ & \multirow[b]{2}{*}{$\mathrm{U}=3139.5$} & \multirow[b]{2}{*}{.251} \\
\hline & $\begin{array}{l}\text { mesleğini } \\
\text { kendi isteği ile } \\
\text { seçme }\end{array}$ & Hayır & 109 & $36.82 \pm 6.176$ & & & 61 & $37.39 \pm 6.568$ & & \\
\hline & \multirow{2}{*}{$\begin{array}{l}\text { Hemşirelikte } \\
\text { örnek alınan } \\
\text { model }\end{array}$} & Evet & 83 & $38.75 \pm 4.355$ & \multirow[t]{2}{*}{$\mathrm{U}=4692.00$} & \multirow[t]{2}{*}{$.011 *$} & 87 & $38.85 \pm 5.987$ & \multirow[t]{2}{*}{$\mathrm{U}=3527.00$} & \multirow[t]{2}{*}{.307} \\
\hline & & Hayır & 142 & $37.00 \pm 5.979$ & & & 89 & $37.43 \pm 6.204$ & & \\
\hline \multirow{2}{*}{$\begin{array}{l}\text { Kariyer } \\
\text { iyimserliği }\end{array}$} & \multirow{2}{*}{ Cinsiyet } & Erkek & 58 & $36.60 \pm 5.553$ & \multirow{2}{*}{$\mathrm{U}=4008,00$} & \multirow{2}{*}{$.050 *$} & 72 & $36.91 \pm 6.274$ & \multirow{2}{*}{$\mathrm{U}=3133.00$} & \multirow{2}{*}{.080} \\
\hline & & Kadın & 167 & $34.75 \pm 5.218$ & & & 103 & $35.21 \pm 3.986$ & & \\
\hline \multirow{2}{*}{$\begin{array}{l}\text { İş piyasasına } \\
\text { ilişkin } \\
\text { algılanan } \\
\text { bilgi }\end{array}$} & \multirow[b]{2}{*}{ Cinsiyet } & Erkek & 57 & $9.72 \pm 2.250$ & \multirow[b]{2}{*}{$\mathrm{U}=3572.00$} & \multirow[b]{2}{*}{$.004 *$} & 72 & $9.15 \pm 2.211$ & \multirow[b]{2}{*}{$\mathrm{U}=3470.00$} & \multirow[b]{2}{*}{.401} \\
\hline & & Kadın & 167 & $8.64 \pm 1.905$ & & & 104 & $8.85 \pm 1.876$ & & \\
\hline \multirow{8}{*}{$\begin{array}{l}\text { Toplam } \\
\text { puan }\end{array}$} & Hemşirelikte & Evet & 83 & $83.48 \pm 8.991$ & \multirow[b]{2}{*}{$\mathrm{U}=4842.00$} & \multirow[b]{2}{*}{$.031 *$} & 86 & $84.18 \pm 9.618$ & \multirow[b]{2}{*}{$\mathrm{U}=3312.50$} & \multirow[b]{2}{*}{.124} \\
\hline & $\begin{array}{l}\text { örnek } \\
\text { aldığınız bir } \\
\text { model }\end{array}$ & Hayır & 141 & $80.80 \pm 11.461$ & & & 89 & $81.80 \pm 11.147$ & & \\
\hline & \multirow[t]{2}{*}{ Cinsiyet } & Erkek & 57 & $84.92 \pm 11.360$ & \multirow{2}{*}{$\mathrm{U}=3912.00$} & \multirow{2}{*}{$.045^{*}$} & 72 & $84.86 \pm 12.752$ & \multirow{2}{*}{$\mathrm{U}=3135.50$} & \\
\hline & & Kadın & 167 & $80.73 \pm 10.243$ & & & 103 & $81.66 \pm 8.322$ & & .082 \\
\hline & & $\begin{array}{l}\text { Klinik } \\
\text { hemşiresi }^{1}\end{array}$ & 85 & $80.07 \pm 13.74$ & & & 58 & $82.36 \pm 12.66$ & & \\
\hline & $\begin{array}{l}\text { Gelecekte } \\
\text { planlanan }\end{array}$ & $\begin{array}{l}\text { Akademisy } \\
\text { en hemşire }^{2}\end{array}$ & 83 & $82.69 \pm 8.17$ & $\mathrm{KW}=11.454$ & & 72 & $82.69 \pm 8.17$ & & \\
\hline & $\begin{array}{l}\text { mesleki } \\
\text { pozisyon }\end{array}$ & $\begin{array}{l}\text { Yönetici } \\
\text { hemşire }^{3}\end{array}$ & 21 & $84.96 \pm 11.29$ & $3>1$ & $.010^{*}$ & 28 & $84.96 \pm 11.29$ & $K W=.657$ & .883 \\
\hline & & $\begin{array}{l}\text { Özel dal } \\
\text { hemşiresi }^{4}\end{array}$ & 35 & $83.00 \pm 9.92$ & & & 17 & $83.00 \pm 9.92$ & & \\
\hline
\end{tabular}

$\overline{\mathrm{X}}$ :Ortalama; SS:Standart sapma; KW: Kruskal-Wallis; U: Mann Whitney U; (*) p<0.05 anlamlı

Merkez kampüs öğrencilerinde KARGEL Ölçeği toplam puanı ile hemşirelikte bir modelin varlığ arasında anlamlı bir fark bulunmuş ( $\mathrm{U}=4842$, $\mathrm{p}=0.031$ ), örnek bir modeli olan öğrencilerin KARGEL ölçek puanlarının daha yüksek olduğu belirlenmiştir. Merkez kampüs öğrencilerinde KARGEL ölçeği toplam puan açısından cinsiyet değişkeni incelendiğinde, aralarında anlamlı bir fark olduğu ( $U=3912, p=0.045)$, erkekler öğrencilerin kariyer geleceğini daha yüksek algıladığ1 bulunmuştur. İlçe kampüsündeki öğrencilerin KARGEL toplam puanı ile değişkenleri arasında anlamlı bir fark saptanmamıştır ( $\mathrm{p}>0.05)$.
Merkez kampüs öğrencilerinde KARGEL toplam puanı ile geleceğe yönelik planlama arasında anlamlı bir fark bulunmuş (KW=11.454, $\mathrm{p}=.010)$, bu farkın yönetici hemşire olmayı planlayanlar ile klinik hemşiresi olarak çalışmayı planlayanlardan kaynaklandığı belirlenmiştir. İlçe kampüs öğrencilerinin tanitıcı özellikleri ile KARGEL Ölçeği toplam puan ve alt boyut puanları arasında bir anlamlı bir fark bulunmamıştır ( $\mathrm{p}>0.05)$.

\section{Tartışma}

İnsanların gelecek planlarını şekillendiren kariyer kavram1, bireysel ve mesleki kimliğin, sosyal statüsünün ve yaşam tarzının oluşmasında büyük önem taşımaktadır (Savickas ve Porfeli, 
2012). Araștırmamızda iki farklı fakültede öğrenim gören hemşirelik öğrencilerinin kariyer geleceğine ilişkin değerlendirmeleri incelenmiştir. Araştırmamızda her iki fakülte öğrencilerinin çoğunluğu hemşirelik bölümünü üniversiteye giriş puanı ve iş bulma olanağına göre tercih ettiği görülmektedir. Gelişmekte olan ülkelerde çoğunlukla dışsal sebeplerle meslek seçimi yapıldı ğ bildirilmektedir (Bastick, 2000). Bizim çalışmamızda ögrencilerin hemşirelik bölümünü tercih etmesinin temel nedeninin bireysel özellikleri ve yeteneklerinden ziyade üniversite yerleşme puanı ve iş bulma kaygısı olduğu, bu durumunda sağlık alanında istihdam olanağının yüksek olmasıyla ilişkili olduğu düşünülmektedir. Meslek tercih nedenleri çoğunlukla içsel (ilgi, mesleği sevme, sağlıkçı yakını olması, kişilik özelliği, insanları sevme vb.) ve dişsal (iş garantisi, ekonomi, aile isteği, bask1, puan vb.) faktörler olarak sinıflandırılmaktadır (Halis, 2013; Önler ve Varol Saraçoğlu, 2010). Ülkemizde yapılan çalışmalarda da öğrencilerin dişsal faktörler nedeniyle hemşirelik mesleğini seçtikleri gösterilmiştir (Kızğut ve Ergöl, 2011; Şirin ve ark., 2008; Zencir ve Eşer, 2016).

Mesleği isteyerek tercih etme öğrencilerin mesleki kariyer gelişimlerine etkisi büyüktür (Zencir ve Eşer, 2016). Bu araştırmada merkez kampüs ve ilçe kampüs öğrencilerinin çoğunluğunun (sırasıyla \%52, \%65) kendi isteği ile hemşirelik mesleğini seçtiği belirlenmiştir. Bizim araştırmamızda elde ettiğimiz bu sonucun zorlu bir ortaöğretim dönemi sonunda kariyerlerine ilişkin seçim yapan öğrencilerin çoğunlukla dişsal faktörleri göz önüne alması ile ilişkili olduğu düşünülmektedir. Karadaş ve arkadaşlarının (2017), Altuntaş ve arkadaşlarının (2005) araştırma sonuçlarında öğrencilerin çoğunluğunun hemşireliği isteyerek, Yıldırım ve arkadaşlarının (2011) çalışmasının ise istemeyerek tercih ettiği bulunmuștur. Lisans eğitiminin başlamasıyla bulundukları eğitim ortamının öğretim elemanları ve sağlık kuruluşları tarafindan çok yönlü desteklenmesi, öğrencilerin ilgi alanlarını ve mesleki değerlerini olumlu etkilemektedir (Lazarides ve ark., 2016; Zencir ve Eşer, 2016). Dolayısıyla bu dönemde kendi isteğiyle hemşirelik mesleğini seçen ya da seçmeyen öğrencilerin, meslekle ilgili görüşleri değişebilir. Bu durumun hemşirelerin ilerleyen yıllarda iş doyumunu artırabileceği ve meslekten ayrılmaları önleyebileceği düşünülmektedir.

Öğrencilerin \%72.5'inin hemşirelik bölümünü ilk sıralarda tercih ettiği saptanmıștır. Bu sonuç hemşirelik öğrencileriyle yapılan bazı çalışmalarla uyumlu iken (Çiftçi ve ark., 2011; Nazik ve Arslan, 2014; Zencir ve Eşer, 2016), bazı çalışmalarla (Şirin ve ark., 2016; Lai ve ark., 2008; Cürcani ve ark., 2014) uyumlu değildir. Bu durumun üniversite seçme sınavının çoğunlukla karar verme sürecinin henüz tam yerleşmediği ergenlik dönemine rastlamasının ve puana göre çok sayıda mesleği tercih listesine yazmasının bir sonucu olduğu varsayılmaktadır.

Araştırmamızda merkez kampüsteki öğrenciler daha çok klinik hemşiresi (\%38) ve akademisyen (\%37) olmak istediklerini belirtmişlerdir. İlçe kampüs öğrencilerinde benzer bulgular bulunmuş olup klinik hemşiresi olmak isteyenlerin (\%33), akademik alanda ilerlemek isteyenlerden (\%41) daha düşük olduğu bulunmuştur. Ülkemizde yapılan diğer çalışmalarda öğrencilerin akademik alanda ilerlemek istediği saptanmıştır (Altuntaş ve ark., 2005; Çiftçi ve ark., 2011; Karadaş ve ark., 2017). Merkez fakülte ögrencileri tıp fakültesi hastanesinde çok farklı hemşirelik uzmanlık alanları ve farklı yetkinlikte hemşire modelleri gözlemleyebilmektedir. İlçe kampüsünde yer alan öğrenciler ise sınırlı hemşirelik uzmanlık alanlarının yer aldığı daha küçük hastanelerde gözlem yapabilmektedir. Dolayısıyla öğrenci hemşirelerin klinik uygulama alanlarında gözlemledikleri hemşirelik uzmanlık alanlarının kariyer geleceğini etkilediği düşünülmektedir. İlçe kampüs öğrencilerinin merkez kampüs öğrencilerine göre sayılarının az olması, dolayısıyla öğretim elemanları ile daha fazla etkileşimde olması akademik alanda ilerlemek istemelerinin sebebi olabilir. Aynı zamanda araştırmamızda merkez fakültede, hemşirelikte örnek modeli olan öğrencilerin KU ve KARGEL ölçek puan ortalamasının ilçe kampüsündeki öğrencilere göre daha yüksek olarak bulunması bu düşünceyi desteklemektedir.

Araştırmamızda KARGEL ölçeği ve alt boyutları $\mathrm{KU}, \mathrm{KI}$ ve $\mathrm{AB}$ puan ortalamalarının orta düzeyde olduğu, puan ortalamaları açısından iki fakülte arasında anlamlı bir fark olmadığ 1 görülmektedir. İki fakültenin sosyal aktivite ve öğrenim koşulları, klinik uygulama alanları birbirinden farklıdır. Araştırmamızda öğrenim görülen okulun lokalizasyonun, sosyal aktivite düzeyinin KARGEL ölçek puanlarına yansımadığı görülmektedir. Literatürde hemşirelik öğrencileriyle yapılan çalışmalarda KU ve Kİ düzeylerinin yüksek olduğu (Coon, 2008; Karadaş ve ark., 2017; Siyez ve Yusupu, 2015), gelecekle ilgili duygu ve beklentilerin olumlu bulunduğu (Şirin ve ark., 2008; 
Yalçın ve Açıkgöz, 2014) çalışmalar mevcuttur. Öğrenciler üniversite sınavı sonrası bölüm seçimi yaparken mesleğin ekonomik koşullarını, maddi kazancını, çalışma şartlarını ve öğrenim görünen okulun sosyal aktivitelerini dikkate almaktadir (Halis, 2013; Önler ve Varol Saraçoğlu, 2010).

Araştırmamızda her iki kampüs öğrencilerinin KU puan ortalaması ile cinsiyet arasında anlamlı bir fark saptanmamıștır. Ülkemizde son y1llarda erkek hemşire sayısındaki artış, bakıș açısının değișmesi gibi sebeplerle KU'yu, öğrenciler arasındaki cinsiyet farkının etkilemediği düşünülmektedir. Yapılan bazı çalışmalarda benzer sonuçlar gösterilmektedir (Tian ve Fan, 2014; Hirschi, 2009; Ginevra ve ark., 2017). Merkez kampüste öğrencilerinin cinsiyete göre $\mathrm{KI}$ ve $\mathrm{AB}$ ölçek puan ortalamaları arasında anlamlı bir fark tespit edilmiştir. Tablo 3 incelendiğinde erkek öğrencilerin $\mathrm{KI}$ ve $\mathrm{AB}$ puan ortalamaları kadın öğrencilere göre daha yüksek bulunmuştur. Türk toplum kültürünün bir özelliği olarak erkeklerin ailenin ekonomik sorumluluğunu alma eğilimi nedeniyle erkek öğrencilerde $\mathrm{KI}$ ve $\mathrm{AB}$ puanının daha yüksek olduğu düşünülmektedir. Karadaş ve arkadaşlarının (2017) çalışmasında da erkek öğrencilerin $\mathrm{AB}$ puan ortalamasının kız öğrencilere göre daha yüksek olduğu bildirilmiștir.

Araştırmamızda merkez kampüs öğrencilerinin kariyer geleceğinde akademik ve klinik uygulama alanlarının etkisinin olduğu görülmektedir. Literatürde hemşirelik lisans öğrencilerinin yaşam boyu kariyer olarak hemşireliği seçme hevesini ve motivasyonunu kişilik özellikleri, klinik ortam, ağır iş yükü ve iş güvensizliği gibi ciddi şekilde engelleyen birçok faktör sıralanmaktadır. $\mathrm{Bu}$ faktörler nedeniyle öğrenci ve mezun hemşirelerin meslekten ayrılma oranlarının yüksek olduğu bildirilmektedir (Lyu ve ark., 2016). Meslekten ayrılmaların incelendiği bir sistematik derlemede, Avrupa'da hemșirelik lisans öğrencilerinin neredeyse yarısının okuldan ayrılmayı düşündüğü (Lancia ve ark., 2013), ABD'de yeni mezun olan hemşirelerin yaklaşık \%10.8'inin hemşirelik mesleğinden ayrıldığ 1 (Brewer ve ark., 2015), Çin'de hemşirelik birinci sınıf öğrencilerinin yaklaşık \%40'ının diğer branşlara geçmeyi istediği gösterilmektedir (Yuan ve ark., 2016). Hemşirelik istihdamı ve mesleki devir hızının düşürülmesi dünya çapında öncelikli olarak kabul edilmekte ve bu mesleğin gelecek nesillerini eğitme çabalarını desteklemek için birlikte çalışan çok sayıda disipline ihtiyaç olduğu bildirilmektedir (Fang ve ark., 2018).
Hemşirelik lisans öğrencileri mesleki geleceğimizin ana kaynağıdır ve kariyer motivasyonlarını yükseltmek, onları hemşirelikte tutmak için önemli olacaktır.

\section{Sonuç ve öneriler}

$\mathrm{Bu}$ araştırmada kariyer planlama yeteneğinin gelişmesinde "bir modeli örnek alma, farklı mesleki pozisyonları gözlemleme ve mesleği isteyerek seçme" faktörlerinin aracılık rolü oynadığ 1 dolayısıyla öğrencilerin kariyer planlamaya ilişkin görüşlerinin akademik ve kinik ortamdan etkilendiği görülmektedir. $\mathrm{Bu}$ nedenle okullar, eğitimciler, klinik alandaki profesyonellerin hemșirelik lisans öğrencilerinin kendilerine özgü kariyer motivasyonuna daha fazla önem vermeli, daha iyimser olmalarını teşvik etmeli, daha profesyonel bir eğitim ortamı sunmalı ve kariyer uyumlarını teşvik etmek için rehberlik sağlamalıdır.

\section{Teşekkür}

Çalışmaya katılan hemşirelik öğrencilerine teşekkür ederiz.

\section{Araştırmanın Etik Yönü/ Ethics Committee Approval: Araştırma Helsinki Deklerasyonu Prensipleri'ne uygun olarak yapılmış, bir üniversitenin Klinik Araştırmalar Etik Kurulu'ndan etik kurul onay1 (Sayı:70904504/277, Tarih: 29.04.2020) alınmıştır. Araştırma için hazırlanan anket formunun giriş bölümünde araştırma hakkında bilgi verilmiştir. Araştırmaya katılmayı kabul edildiğine dair soruya olumlu yanıt verenler formu doldurmuşlar, böylelikle katılımcıların izni alınmıştır.}

Hakem/Peer-review: Dış hakem değerlendirmesi. Yazar Katkısi/Author Contributions: Fikir/kavram: EI; Tasarım: Eİ, SK; Danışmanlık: Eİ; Veri toplama ve/veya Veri İşleme: AE, ŞA, ENT, FE; Analiz ve/veya Yorum: EI, SK; Kaynak tarama, EI, Makalenin Yazımı: Eİ; Eleştirel inceleme: SK.

Çıkar çatışması/Conflict of interest: Çalışmada herhangi bir çıkar çatışması söz konusu değildir.

Finansal Destek/Financial Disclosure: $\mathrm{Bu}$ çalışma herhangi bir kurum ya da kuruluş tarafından desteklenmemiştir. 


\section{Çalışma Literatüre Ne Kattı?}

- Hemşirelik öğrencilerinin kariyer geleceğine ilişkin eğitim, bilgilendirme, seminer gibi organizasyonlara ihtiyaç olduğu;

- Hemşirelik öğrencilerinin kariyer planlamasında okuldaki öğretim elamanlarının rol model olarak görüldüğü;

- Hemşirelik öğrencilerinin klinik ortamda gözlemlediği hemşire meslektaşlarının ve klinik uygulama alanların yeterliliğinin kariyer geleceklerinin şekillendirmeye katkı sağladığ saptanmıştır.

\section{Kaynaklar}

Altuntaş S, Korkmaz Ş, Baykal Ü, Özyürek A, Pazar Z, Uz Ş, Bahar T, Tülay N. (2005). Hemşire öğrencilerin kariyer yönelimleri ve bunu etkileyen faktörler, İstanbul Üniversitesi Florence Nightingale Hemşirelik Fakültesi Dergisi, 13(55), 179-197.

Bastick T. (2000). Why teacher trainees choose the teaching profession: Comparing trainees in metropolitan and developing countries. International Review of Education/Internationale Zeitschrift für Erziehungswissenschaft/Revue Internationale de l'Education, 46(3/4), 343-349.

Brewer CS, Chao YY, Colder CR, Kovner CT, Chacko TP. (2015). A structural equation model of turnover for a longitudinal survey among early career registered nurse, International Journal of Nursing Studies, 52(11), 1735-45.

Cevher E. (2015). Üniversitelerde kariyer planlama faaliyetleri ekseninde kariyer merkezlerine yönelik bir araştırma, Karabük Üniversitesi Sosyal Bilimler Enstitüsü Dergisi, 5(2), 164-177.

Chan SHJ, Mai X. (2015). The relation of career adaptability to satisfaction and turnover intentions, Journal of Vocational Behavior, 89, 130-139.

Coon KL. (2008). Predicting career decision-making difficulties among undergraduate students: the role of career decision making self efficacy, career optimism, and coping, Southern Illinois University at Carbondale.

Cürcani M, Kavurmaci M, Küçükoğlu S. (2014). Erkekler Neden hemşire olmak istiyor? Anadolu Hemşirelik ve Sağlık Bilimleri Dergisi, 17(1), 1-5.

Çiftçi EG, Bülbül SF, Muluk NB, Duyan GÇ, Yılmaz A. (2011). Sağlık bilimleri fakültesini tercih eden öğrencilerin, üniversite ve meslek tercihlerinde etkili olan faktörler (Kırıkkale Üniversitesi örneği), Kartal Eğitim ve Araştırma Hastanesi Tıp Dergisi, 22(3), $151-160$

Douglass RP, Duffy RD. (2015). Calling and career adaptability among undergraduate students, Journal of Vocational Behavior, 86,58-65.
Fang W, Zhang Y, Mei J, Chai X, Fan X. (2018). Relationships between optimism, educational environment, career adaptability and career motivation in nursing undergraduates: A crosssectional stud, Nurse Education Today, 68, 33-39.

Ginevra MC, Sgaramella TM, Ferrari L, Nota L, Santilli S, Soresi T. (2017). Visions about future: A new scale assessing optimism, pessimism, and hope in adolescents, International Journal for Educational, 17(2), 187-210.

Guan Y, Wang F, Liu H, Ji Y, Jia, X, Fang Z. ve ark. (2014). Career-specific parental behaviors, career exploration and career adaptability: A three-wave investigation among Chinese undergraduates, Journal of Vocational Behavior, 86, 95-103.

Halis M. (2013). Kırgızistanda Üniversite Adaylarının Kariyer Güdüleri Motivasyon Ve Değerleri İlişkisi: Bir Araştırma, Dumlupınar Üniversitesi Sosyal Bilimler Dergisi, 36, 203-217.

Hirschi A. (2009). Career adaptability development in adolescence: Multiple predictors and effect on sense of power and life satisfaction, Journal of Vocational Behavior, 74(2), 145-155.

Imanipour M, Sadooghiasl A, Ghiyasvandian S, Haghani H. (2015). Evaluating the Educational Environment of a Nursing School by Using the DREEM Inventory, Global Journal of Health Science, 7(4), 211-6.

Johnston K, Chen MM, Hauman M. (2013). Use, perception and attitude of university students towards Facebook and Twitter, Electronic Journal of Information Systems Evaluation, 16(3), 201-211.

Kalafat T. (2012). Kariyer Geleceği Ölçeği (KARGEL): Türk örneklemi için psikometrik özelliklerinin incelenmesi, Türk Psikolojik Danışma ve Rehberlik Dergisi, 4(38), 169-179.

Karadaş A, Duran S, Kaynak S. (2017). Hemşirelik öğrencilerinin kariyer planlamaya yönelik görüşlerinin belirlenmesi, SDÜ Sağlık Bilimleri Enstitüsü Dergisi, 8(1), 1-8.

Kızğut S, Ergöl Ş. (2011). Sağlık yüksekokulu öğrencilerinin hemşireliği algılayışı hemşirelik rollerine ve hemşireliğin geleceğine bakışı, Anadolu Hemşirelik ve Sağlık Bilimleri Dergisi, 14(2), 10-15.

Lai H-L, Lin Y-P, Chang H-K, Chen C-J, Peng T-C, Chang F-M. (2008). Is nursing profession my first choice? A follow up survey in pre-registeration student nurse, Nurse education today, 28(6), 768-776.

Lancia L, Petrucci C, Giorgi F, Dante A, Cifone MG. (2013). Academic success or failure in nursing students: results of a retrospective observational study, Nurse Education Today, 33(12), 1501-5.

Lazarides R, Rohowski S, Ohlemann S, Ittel A. (2016). The role of classroom characteristics for students' motivation and career exploration, Educational Psychology, 36(5), 992-1008.

Lyu L, Li G, Li J, Li M. (2016). Nurse turnover research in China: a bibliometric analysis from 2000 to 2015, 
International Journal of Nursing Sciences, 3(2), 208212.

Mahendran R, Lim HA, Verma S, Kua EH. (2015). The impact of the educational environment on career choice and attitudes toward psychiatry, Medical Teacher, 37(5), 494-497.

Nazik E, Arslan S. (2014). Hemşirelik mesleğinin geleceği: öğrencilerin beklentileri, Bozok Tıp Dergisi, 4(1), 33-40.

Negru-Subtirica O, Pop EI, Crocetti E. (2015). Developmental trajectories and reciprocal associations between career adaptability and vocational identity: A three-wave longitudinal study with adolescents, Journal of vocational behavior, 88, 131-142.

Ohme M, Zacher H. (2015). Job performance ratings: The relative importance of mental ability, conscientiousness, and career adaptability, Journal of Vocational Behavior, 87, 161-170.

Rottinghaus PJ, Buelow KL, Matyja A, Schneider M. (2012). The career futures inventory-revised: Measuring dimensions of career adaptability, Journal of Career Assessment, 20(2), 123-139.

Rottinghaus PJ, Day SX, Borgen FH. (2015). The Career Futures Inventory: A measure of career-related adaptability and optimism, Journal of Career Assessment, 13(1), 3-24.

Savickas ML, Porfeli EJ. (2012). Career Adapt-Abilities Scale: Construction, reliability, and measurement equivalence across 13 countries, Journal of vocational behavior, 80(3), 661-673.

Şirin A, Öztürk R, Bezci G, Çakar G, Çoban A. (2008). Hemşirelik öğrencilerinin meslek seçimi ve mesleği uygulamaya yönelik görüşleri, Dirim Tıp Gazetesi, 83(1), 69-75.

Önler E, Varol Saraçoğlu G. (2010). Hemşirelikte meslek seçimi ölçeğinin güvenilirlik ve geçerliliği, Dokuz Eylül Üniversitesi Hemşirelik Yüksekokulu Elektronik Dergisi, 3(2), 78-85.

Siyez DM, Yusupu R. (2015). Üniversite öğrencilerinde kariyer uyumluluğu ve kariyer iyimserliğinin cinsiyet rolü değişkenine göre incelenmesi, ISGUC The Journal of Industrial Relations Human Resources, 17(1), 75-88.

Tian Y. Fan X. (2014). Adversity quotients, environmental variables and career adaptability in student nurses, Journal of Vocational Behavior, 85(3), 251-257.

Waddell J, Spalding K, Canizares G, Navarro J, Connell M, Jancar S, Stinson J, Victor C. (2015). Integrating a Career Planning and Development Program into the Baccalaureate Nursing Curriculum: Part III. Impact on Faculty's Career Satisfaction and Confidence in Providing Student Career Coaching, International Journal of Nursing Education Scholarship, 12, 18390.
Yalçın S, Açıkgöz İ. (2014). Sağlık Bilimleri Fakültesi Son Sınıf Öğrencilerinin Umutsuzluk Düzeylerinin Karşılaştırılması, Mustafa Kemal Üniversitesi Sosyal Bilimler Enstitüsü Dergisi, 11(26), 259-270.

Yıldırım D, Keçeci A, Bulduk S. (2011). How do Turkish nursing students plan their career after the graduation?: a questionnaire survey, Asia Pacific Education Review, 12(3), 373-380.

Yuan Y, Xiangming L, Yuexia L. (2016). Analysis of the status quo and causes of nursing students' desire to change the major, International Journal of Nursing Sciences, 35, 1999-2002.

Zacher H, Griffin, B. (2015). Older workers' age as a moderator of the relationship between career adaptability and job satisfaction, Work, Aging and Retirement, 1(2), 227-236.

Zencir G, Eşer İ. (2016). Nursing Students' Attitudes Towards The Nursing Profession, Nursing Preferred With The Relationship Between: Example of Turkey, Dokuz Eylul University Faculty of Nursing Electronic Journal, 9(2), 30-37. 